Çukurova Üniversitesi Mühendislik Mimarlık Fakültesi Dergisi, 33(4), ss. 31-44, Aralık 2018

Çukurova University Journal of the Faculty of Engineering and Architecture, 33(4), pp. 31-44, December 2018

\title{
Çok Ölçütlü Karar Verme Yöntemleri ile Kağıt Fabrikası Kuruluş Yeri Seçimi
}

\author{
Murat YEŞiLKAYA ${ }^{* 1}$ \\ ${ }^{1}$ Tokat Gaziosmanpaşa Üniversitesi, Niksar Teknik Bilimler Meslek Yüksekokulu, Tokat
}

$\ddot{O} z$

Geliş tarihi: $30.05 .2018 \quad$ Kabul tarihi: 25.12 .2018

Küreselleşen dünya ve artan rekabet şartları göz önünde bulundurulduğunda, işletmelerin başarıları açısından kuruluş yerinin belirlenmesi kritik öneme sahiptir. Türkiye'de ekonomik potansiyeli olan kağıt endüstrisinde kuruluş yeri tespit edilmesi sektör yatırımları açısından önem arz etmektedir. Sektörde özellikle son yıllarda tersine lojistiğin en önemli uygulama alanlarından olan atık kâğıtların geri dönüşümü ile büyük oranda hammadde kaynağı sağlamaktadır. Bu çalışmada, kağıt fabrikası kuruluş yeri tespiti için beş aday şehir arasından en uygun yerin belirlenmesine yönelik bir karar destek modeli önerilmiştir. $\mathrm{Bu}$ maksatla, kuruluş yeri alternatiflerinin çeşitli olması ve kriterlerinin karmaşık olması nedeniyle sıkça kullanılan matematiksel ve mantıksal model temelli çok ölçütlü karar verme yöntemleri kullanılmıştır. Çalışmada kuruluş yeri değerlendirme kriterleri olarak; pazar, işgücü, hammadde, ulaşım, teşvikler, atıklar, enerji ve arazi olarak belirlenmiştir. Uygulamada AHP, TOPSIS ve PROMETHEE yöntemleri ile çözümler yapılmış ve sonuçlar karşılaştırılmış etkin karar verilmiştir. Bu uygulamanın diğer endüstrilerde yapılacak kuruluş yeri seçim problemleri için bir öngörü oluşturacağı düşünülmektedir.

Anahtar Kelimeler: Çok ölçütlü karar, Kuruluş yeri, Kağıt endüstrisi, AHP, TOPSIS, PROMETHEE

\section{Selection of Paper Factory Location Using Multi-Criteria Decision Making Methods}

\begin{abstract}
When taking into consideration of the globalizing world and the increasingly competitive conditions, determination of the location of the establishment has critical importance for success of businesses. In the paper industry which has economic potential in Turkey, determination of the location of establishment is important for sector investments. Recycling of waste papers which is one of the most important application areas of reverse logistics especially in recent years can provide a large part of raw material source. In this study, a decision support model was proposed to determine the most optimal location among five candidate cities for paper factory location. For this purpose, mathematical and logical model-based multi-criteria decision making methods, which are commonly used because of the variety of site location alternatives and the complexity of their criteria, were used. Market, labor, raw material, transportation, incentives, wastes, energy and land were determined as the consideration criteria for establishment location in the study. In the application, solutions were performed with AHP, TOPSIS and PROMETHEE methods and effective decisions were made by comparison of the results. It is believed that this application will provide an insight into the location selection problems to be made in other industries.
\end{abstract}

Keywords: Multi-criteria decision, Location selection, Paper industry, AHP, TOPSIS, PROMETHEE

*Sorumlu yazar (Corresponding author): Murat YEŞILKAYA, murat.yesilkaya@gop.edu.tr 


\section{GíRiș}

Yatırımcılar ve yöneticilerin yatırım kararı verme süreçlerinin önemli bir kısmını oluşturan kuruluş yerinin seçimi, çözülmesi gereken bir sorun olarak uzun yıllardır görülmektedir. Kuruluş yeri çalışmaları endüstriyelleşmenin başladığı $18 \mathrm{yy}$ 'a kadar kişisel ve çevresel etkilerin sonucu olsa da son y1llarda matematiksel ve mantıksal analiz yöntemleri kullanılmaktadır. Stratejik bir karar olan fabrika kuruluş yerinin belirlenmesinde kullanılan en önemli yöntemlerden biri de çok ölçütlü karar verme (ÇÖKV) yöntemleridir. ÇÖKV yöntemleri birçok alternatif kuruluş yeri için sektör bazda önem arz eden kriterleri karşılaştırarak karar verme sürecidir. Bu çalışmada ÇÖKV yöntemleri ile kuruluş yerinin seçimi üzerine Türkiye'de kağıt endüstrisinde bir uygulama yapılacaktır. Türkiye'de kağıt endüstrisindeki ilk atılımı 1936 yılında devlet otoritesi tarafindan kurulan SEKA (Türkiye Selüloz ve Kağıt Fabrikaları A.Ş.) ile olmuştur [1]. SEKA'lar ilk olarak Kocaeli'de kurulmuştur. Daha sonra 1970 yılandan başlayarak sırasıyla Çaycuma (Zonguldak) ve Aksu (Kahramanmaraş), Dalaman (Muğla), Afyonkarahisar, Balıkesir, Taşucu (Mersin) ve Kastamonu kağıt fabrikaları kurulmuştur [2]. 1990'lı yılların başında özel sektörün kağıt endüstrisine yatırımları artmış ve birçok kağıt fabrikası kurulmuştur. SEKA'lar ülke ekonomisindeki değişim ile özel sektöre devir sürecine alınmış 2005 yılında kurumun faaliyetlerine tamamen son verilmiștir [3].

Kağıt endüstrisinde fabrika kuruluş yerinin belirlenmesi işletmeler açısından hem maliyet hem de sürdürülebilirlik için önem arz etmektedir. Özellikle fabrika kurulum işlemlerinde yoğun bir iş gücü ve yüksek yatırm maliyetli üretim sistemlerinin kurulması gereği göz önüne alındığında yöneticiler için fabrika kuruluş yerinin tespiti stratejik bir öneme sahiptir. Türkiye'de ilk yıllardan günümüze kağıt fabrika kuruluş yerleri belirlenirken birçok etmene dikkat edildiği görülmektedir. Genellikle kağıt fabrikaları ilk y1llarda hammadde yoğun bir sektör olduğu için orman varlıklarının yoğun olduğu bölgelerin (Çaycuma, Aksu, Dalaman vb.) seçildiği görülmektedir [4]. Ayrıca selüloz üretimi (kağıt hammaddesi) esnasından yoğun su ihtiyacından dolayı su kaynaklarının yakınında (Taşucu, Aksu vb.) kurulduğu gözlemlenmiştir. Fabrika kuruluş için en önemli faktörlerin başında gelen pazara yakınlık (Kocaeli) yine kağıt fabrikalarının kuruluşunda göz önüne alınmıştır [5]. Özel sektör yatırımları ve teşvikler ile sektörün ana hammaddesi \%90'ın üzerinde bir oranda atık kağıtlar ve doğrudan selüloz kullanımı olmuştur [6-7]. Dolayısıyla kağıt endüstrisi hammadde yoğun bir sektörden pazar yoğun bir sektör haline bürünmüştür. Atık kağıtların toplanarak yeniden işlenmesi üzerine bir tersine lojistik sistemi kurulmuştur. Attk kağıttan karton, mukavva ve oluklu mukavva üretimi gerçekleştirilmesi yapılmaktadır. Kağıt endüstrisinde rekabet gücünü zayıflatan en önemli faktörlerin başında üretim maliyetlerinin yüksekliği gelmektedir. Sektörün daha verimli olabilmesi için hammadde, malzeme, işgücü, enerji ve çevre şartlarını göz önüne alması gerekmektedir [8].

$\mathrm{Bu}$ çalışmada, Akdeniz Bölgesinde (Adana, Mersin, Kahramanmaraş, Osmaniye ve Hatay) atık kâğıttan üretim yapacak kağıt fabrikası kuruluş yerinin tespiti ÇÖKV yöntemleri ile bir uygulama yapılacaktır. Bu maksatla ilk olarak Türkiye'deki kağıt endüstrisinin potansiyelinden bahsedilmiştir. Daha sonra ise kuruluş yeri seçim problemleri üzerine yapılmış çalışmalar ve ÇÖKV yöntemlerinin kuruluş yeri seçim analizinde kullanım uygunluğu araştırılmıştır. Bir sonraki bölümde uygulamada kullanılan AHP, TOPSIS ve PROMETHEE algoritmaları açılanmıştır. Son bölümde ise uygulamalardan çözümler elde edilmiş ve sonuçlar karşılaştırılarak en uygun kuruluş yerinin seçimi yapılmıştır.

\section{LITERATÜR CALISYMASI}

ÇÖKV yöntemleri; tedarikçi seçiminden [9], yatırım projelerinin değerlendirilmesine [10], işgücü planlamadan [11], kuruluş yeri seçimine [12] kadar birçok farklı planlama aşamalarında etkili ve yoğun bir şekilde kullanım alanı bulmaktadır. Ayrıca sağlık, ekonomi-finans, bilişim, otomotiv, enerji, savunma, tarım gibi sektörlerde stratejik karar verme süreçlerinde etkin olarak rol oynamaktadır [13]. 
Kuruluş yer seçimi, bir işletme yatırımının ilk aşaması olan ve üretim/hizmet süreçlerini sürdüreceği coğrafi konumlarını belirleme sürecidir. Kuruluş yeri kararı ise, alternatifler arasında tanımlama, analiz etme, değerlendirme ve seçim sürecini kapsamaktadır. Bir tesis yeri seçmek, işletmeler için önemli bir karardır, çünkü kurulum maliyetleri yüksek ve tekrar kurulum çok zordur. Ayrica tesisin kuruluş yerinde uzun süre faaliyet göstermesi istenir [14]. Tesis yerinin kararları, önemli sermaye yatırımı gerektirir ve malların üretimi, dağıtımı konusunda uzun vadeli kısıtlamalar doğurur. Bu problemler karmaşıktır ve çoğu gerçek dünya problemi gibi kendine özgü bir dizi somut ve soyut faktörlere bağlıdır [15]. Kuruluş yerinin belirlenmesinde genel kabul gören amaçlar; kurulum maliyetini düşürme, tesis, depo ve talep noktaları arası mesafeyi en aza indirme, toplam maliyetleri düşürme, müşteri taleplerinin en iyi şekilde karşılanması olarak sıralanmaktadır [16]. Özellikler son yıllarda enerji maliyetleri, çevre ve sosyal hedeflerde önemli kısitlamalar olarak görülmektedir [17].

Kuruluş yerinin belirlenmesiyle ilgili ilk çalışmalar 17. yy'da Fermat ve daha sonra 20. yy'da Weber tarafından yapmıştır [18]. Son yıllarda ise kuruluş yeri seçiminde kullanılan yöntemler incelendiğinde; sezgisel algoritmalar, doğrusal programlama, tamsayı programlama, dinamik programlama, doğrusal olmayan programlama, hedef programlama, çok ölçütlü karar verme ve çoklu regresyon analizi gibi çok farklı yöntemler olduğu ve farklı sektörlerde uygulandığ görülmektedir [19]. Bu yaklaşımlardan biri olan ve etkin sonuç veren ÇÖKV yöntemleri, hem nitel hem de nicel kriterleri dikkate alarak tesis yeri alternatifini seçmek için geliştirilmiştir. ÇÖKV yöntemleri ile ilgili kuruluş yeri seçimi için çok farklı sektörlerde kullanım alanı bulmaktadır. Özcan ve arkadaşları [20] yaptıkları uygulamada, AHP tabanlı TOPSIS, ELECTRE ve Gri teori yöntemleri ile perakende sektörü için beş alternatif arasından en uygun depo yerinin karşılaştırmalı analizi Simos kriterleri kullanılarak yapmıştır. Tavakkoli ve arkadaşları [21] yaptıkları uygulamada, İran' da bir ev aletleri fabrikası kuruluş yerini tespiti AHP tabanlı VIKOR yöntemi, Mousavi ve arkadaşları [22] yine aynı veriler ile
Delphi ve AHP tabanlı PROMETHEE yöntemleri ile yapılmıştır. Bu maksatla konusunda uzmanlarla görülmüş ve nitelikli işgücü, büyüme olanağı, hammadde durumu, yatırım maliyeti ve riskler kriter olarak belirlenmiştir. Choudhary ve Shankar [23] yaptıkları çalışmada, bulanık AHP tabanlı TOPSİS yöntemiyle Hindistan'da termik santrali yerinin tespiti yapılmıştır. Kriter olarak maliyet, kaynakların kullanılabilirliği, sosyo-ekonomik gelişme ulaşım, biyolojik-fiziksel çevre özelliklerini kullanmışlardır. Yapılan çalışmalar bir bütün olarak incelendiğinde, maliyet, pazar, hammadde ve çevre faktörleri kuruluş yeri seçiminde öne çıkan faktörler olarak görülmektedir. Ayrıca sektörlere göre özel kriterlerinde olduğu söylenilebilir.

Kağıt fabrikalarının kuruluş yeri seçiminde çevresel faktörler, girdi fiyatları, pazar büyüklüğü ve özellikle atık kağıt fiyatlarının önem arz etmektedir [24]. ÇÖKV yöntemleri ile kağıt fabrikası kuruluş yerinin tespiti ile ilgili yapılmış çalışmalar çok kısıtlıdır. Braglia ve Gabbrielli [25] yaptıkları çalışmada, İtalya'da yeni kurulacak kağıt fabrikası yerinin tespiti için üç farklı alternatif arasından AHP yöntemi ile seçim yapılmıştır. Yöneticilerle yapılan görüşmeler sonunda kriterler sırasıyla; maliyet, hammadde (atık kağıt, selüloz), işgücü, taşıma, yapım maliyeti, enerji (buhar gücü), ulaşım yapıs1, pazar, yasal düzenlemeler ve çevre faktörleri olmak üzere geniş bir hiyerarşik yap1 oluşturulmuştur. Vali ve arkadaşları [26] yaptıkları çalışmada İran'da tarımsal atıktan kağıt üretimi yapacak fabrika yerinin seçimi AHP yöntemi ile yapılmıştır. Kriter önem sırasına göre hammadde, pazar, alt yapı, çevre, yasal düzenlemeler ve işgücü olarak belirlenmiştir. Barimani ve arkadaşları [27] yaptıkları çalışmada, İran'da kurulacak kağıt fabrikası için üç alternatif yer arasından kuruluş yeri seçimi AHP yöntemi ile yapılmıştır. Kriterler olarak önem sırası göre, hammadde, pazar, ulaşım, yasal düzenlemeler ve işgücü olarak tespit edilmiştir.

\section{3. ÇOK ÖLÇÜTLÜ KARAR VERME YÖNTEMLERİ}

ÇÖKV, farklı etkileri temsil eden belirlenmiş kriterlere göre en uygun çözümü belirleme süreci 
olarak ifade edilir [28]. ÇÖKV yöntemleri, çoklu hedeflerin varlığında karar verme sürecini ele alarak bir karar vericinin ölçülebilir veya ölçülebilir olmayan birden fazla ölçüt arasından seçim yapmasına olanak tanır. Hedefler genellikle çelişkilidir ve bu nedenle çözüm, karar vericinin tercihlerine büyük ölçüde bağımlıdır ve bir uzlaşma olması zorunludur [29]. ÇÖKV; sınırlı sayıda alternatifin seçimi, sıralanma, sınıflandırması, ağırlıklandırılması veya seçim maksadıyla genellikle ölçeklendirilmiş, karmaşık ve çok sayıda ölçütlerin kullanılması ile oluşan matematiksel modelleri olarak ifade edilir [30].

\subsection{AHP Algoritması}

AHP (Analitik Hiyerarşi Prosesi), ilk olarak Myers ve Alpert [31] tarafindan kullanılmış, 1970'li yıllarda ise Saaty tarafından çoklu kriter içeren karmaşık karar verme süreçleri için matematiksel teorisi geliştirilmiştir [32]. AHP yönteminde amaç, birden farklı kriterler ve alternatiflerden oluşan hiyerarşik bir ağ yapısı ile uygun çözümün analiz edilmesi modelidir. AHP'nin algoritma adımlar halinde verilmiştir [33].

Adım 1: Hiyerarşik yapı kriterler alt kriterleri ve alternatifler belirlenerek tasarlanır.

Adım 2: Her bir kriter ve alternatifler kendi aralarında ikili olarak karşılaştırılırlar ve göreceli ağırlıkları belirlenir. Kriterlerin ağırlıkları belirlemede Çizelge 1'de gösterilen 1-9 arası numaralandırılmış ölçek yoğun olarak kullanılan yöntemdir [34].

Çizelge 1. İkili karşılaştırma ölçeği [34-35]

\begin{tabular}{|c|l|}
\hline $\begin{array}{c}\text { Önem } \\
\text { değerleri }\end{array}$ & Değer tanımları \\
\hline $\mathbf{1}$ & Her iki faktörde eşit değere sahip \\
\hline $\mathbf{3}$ & 1. faktör 2. faktörden daha önemli \\
\hline $\mathbf{5}$ & 1. faktör 2. faktörden çok önemli \\
\hline $\mathbf{7}$ & $\begin{array}{l}\text { 1. faktör 2. faktöre göre çok güçlü bir öneme } \\
\text { sahip }\end{array}$ \\
\hline $\mathbf{9}$ & $\begin{array}{l}\text { 1. faktör 2. faktöre göre mutlak üstün bir öneme } \\
\text { sahip }\end{array}$ \\
\hline $\mathbf{2 , 4 , 6 , 8}$ & Ara değerler \\
\hline
\end{tabular}

Adım 3: (A matrisi): Alternatiflerin ve kriterlerin kendi aralarında ikili karşılaştırmaları ile elde edilen sonuçlar kare matris şekline dönüştürülür.
İkili karşılaştırma matrisi örneği Eşitlik 1'de gösterilmektedir [34].

$$
\mathrm{A}=\left[\begin{array}{ccccc}
1 & \mathrm{a}_{21} & \mathrm{a}_{31} & \ldots & \mathrm{a}_{\mathrm{n} 1} \\
1 / \mathrm{a}_{21} & 1 & \mathrm{a}_{32} & \ldots & \mathrm{a}_{\mathrm{n} 2} \\
1 / \mathrm{a}_{31} & 1 / \mathrm{a}_{32} & 1 & \ldots & \mathrm{a}_{\mathrm{n} 3} \\
\vdots & \vdots & \vdots & \ddots & \vdots \\
1 / \mathrm{a}_{\mathrm{n} 1} & 1 / \mathrm{a}_{\mathrm{n} 2} & 1 / \mathrm{a}_{\mathrm{n} 3} & \cdots & 1
\end{array}\right]_{\mathrm{nxn}}
$$

Adım 4: İkili karşılaştırma matrislerinin her bir değerinin bulunduğu sütun toplamına bölünmesi ile normalleştirilmiş matris elde edilir [37].

Adım 4.1: Normalize edilmiş matrisin her bir satır değerinin ortalaması alınarak özvektör bulunur. Öz vektör, ilgili matristeki her bir kriter yada alternatifin diğer kriter ya da alternatiflere göre önem derecesini ifade eder.

Adım 5: Tutarlılık oranı hesabı; ikili karşılaştırma matrisi ile özvektör matrisinin çarpımı ile sütun vektörü matrisi bulunur. Bulunan bu matris de özvektör ile bölünerek temel değer matrisi bulunur. Temel değer matrisinin ortalaması ise lamda değerini verir. Her ikili karşılaştırma matrisi için tutarlılık oranı (CR) hesaplanır ve bu oranın 0,10 'un altında olması uygunluk için istenir. Eğer bu değerin altında sonuç elde edilirse tutarsızlık vardır, sonuçların tekrar değerlendirilmesi gerekir. Hesaplamalar Eşitlik 2 ve Eşitlik 3 kullanılarak yapilır [32].

$\lambda_{\max }=\frac{\sum_{\mathrm{i}=1}^{\mathrm{n}} \mathrm{d}_{\mathrm{i}} / \mathrm{w}_{\mathrm{i}}}{\mathrm{n}} \quad \mathrm{CR}=\frac{\lambda-\mathrm{n}}{(\mathrm{n}-1) \times \mathrm{RI}}$

Tutarlılık oranı hesaplamasında kullanılan sabit sayılardan meydana gelen ve $\mathrm{n}$ değerine göre belirlenen rassallık endeksi (RI) değerleri Çizelge 2'de verilmiştir.

Çizelge 2. Rassallık endeksi [34]

\begin{tabular}{|c|c|c|c|c|c|c|}
\hline $\mathbf{n}$ & & 1 & 2 & 3 & 4 & 5 \\
\hline $\mathbf{R I}$ & & 0 & 0 & 0,58 & 0,9 & 1,12 \\
\hline $\mathbf{n}$ & & 6 & 7 & 8 & 9 & 10 \\
\hline $\mathbf{R I}$ & & 1,24 & 1,32 & 1,41 & 1,45 & 1,49 \\
\hline
\end{tabular}

Adım 6: Nihai sıranın belirlenmesi; hiyerarşik yapıdaki $\mathrm{n}$ adet kriterin her biri için oluşturulan $\mathrm{mxl}$ boyutundaki üstünlük sütün vektörleri bir araya 
getirilerek mxn boyutundaki DW karar matrisi eşitlik 4'de gibi oluşturulur. R sonuç vektörüne ise DW matrisi ile W üstünlük vektörünün çarpımı ile ulaşılır. Eşitlik 4'de verilmiştir. Bu vektörde en büyük değere sahip alternatif en uygun seçenek olarak belirlenir [33-34].

$$
\mathrm{DW}=\left[\mathrm{w}_{\mathrm{ij}}\right]_{\mathrm{mxn}} \quad \mathrm{R}=\mathrm{DW} \times \mathrm{W}
$$

\subsection{TOPSIS Algoritması}

Yoon ve Hwang [37] tarafindan ÇÖKV tekniği olarak geliştirilmiştir. TOPSIS (Technique for Order Preference by Similarity to Ideal Solution) yöntemi ideal çözüme en yakın olan çözüm alternatifinin bulunması mantığı ile çalışır. Alternatifler arasından kriterlere göre çözüm için en iyi olandan en kötü olana doğru bir sıralama sunar. Çözüm için aşağıdaki adımlar izlenir [38].

Adım 1: Amaçların belirlenmesi ve değerlendirme kriterlerinin tanımlanması yapılır.

Adım 2: Karar Matrisi A oluşturulması AHP yönteminde açıkladığı gibi yapılmaktadır.

Adım 3: Karar matrisinde her bir değer için, değerin aynı sütundaki yer alan değerlerin kök içinde kareleri toplamina bölünmesi standart karar matrisinin (R) bulunur. Normalizasyon işlemi sonunda Eşitlik 5'de gösterilen R matrisi elde edilir [39].

$r_{i j}=\frac{y_{i j}}{\sqrt{\sum_{i=1}^{n} y_{i j}^{2}}} \quad R_{n k}=\left[\begin{array}{cccc}r_{11} & r_{12} & \ldots & r_{1 k} \\ r_{21} & r_{22} & \ldots & r_{2 k} \\ \vdots & \vdots & \ddots & \vdots \\ r_{n 1} & r_{n 2} & \cdots & r_{n k}\end{array}\right]$

Adım 4: Ağırlıklı standart karar matrisi (V); R matrisinin belirlenen ağırlık değerleri ile çarpılması sonucu elde edilen matristir.

Adım 5: İdeal (A+ ) ve negatif ideal (A-) çözümleri; $\mathrm{V}$ matrisinde bulunan değerlerin sütunların en büyük değerleri ile $\mathrm{A}+$ matrisi, en küçük değerleri ile A- matrisi oluşturulur. I fayda $\mathrm{J}$ ise maliyeti göstermektedir. Eşitlik 6 ve Eşitlik 7 kullanılarak hesaplanır [40].

$\mathrm{A}^{*}=\left\{\left(\max _{\mathrm{i}} \quad \mathrm{v}_{\mathrm{ij}} \mid \mathrm{j} \in \mathrm{I}\right),\left(\min _{\mathrm{i}} \quad \mathrm{v}_{\mathrm{ij}} \mid \mathrm{j} \in \mathrm{J}\right)\right\}$

$\mathrm{A}^{-}=\left\{\left(\min _{\mathrm{i}} \mathrm{v}_{\mathrm{ij}} \mid \mathrm{j} \in \mathrm{I}\right),\left(\max _{\mathrm{i}} \quad \mathrm{v}_{\mathrm{ij}} \mid \mathrm{j} \in \mathrm{J}\right)\right\}$
Adım 6: Ayırım Ölçülerinin Hesaplanması: Maksimum ideal noktaya olan uzaklık Eşitlik 8'de görülen formülle hesaplanır [38].

$\mathrm{S}_{\mathrm{i}}^{*}=\sqrt{\sum_{\mathrm{j}=1}^{\mathrm{n}}\left(\mathrm{v}_{\mathrm{ij}}-\mathrm{v}_{\mathrm{j}}^{*}\right)^{2}}$

Minimum ideal noktaya olan uzaklık aşağıdaki Eşitlik 9 ile hesaplanır. [38].

$\mathrm{S}_{\mathrm{i}}^{-}=\sqrt{\sum_{\mathrm{j}=1}^{\mathrm{n}}\left(\mathrm{v}_{\mathrm{ij}}-\mathrm{v}_{\mathrm{j}}^{-}\right)^{2}}$

Adım 7: İdeal Çözüme Göreli Yakınlığın Hesaplanması: Eşitlik 10'a göre bulunur [38-39].

$\mathrm{C}_{\mathrm{i}}^{*}=\frac{\mathrm{S}_{\mathrm{i}}^{-}}{\mathrm{S}_{\mathrm{i}}^{-}+\mathrm{S}_{\mathrm{i}}^{*}} \quad 0 \leq \mathrm{C}_{\mathrm{i}}^{*} \leq 1$

Adım 8: alternatifler ideal çözüme göreli yakınlık (*Ci) değerlerine göre en uygun karar sıralaması belirlenir. Maksimum değere sahip (*Ci) alternatifi en uygun karar noktası olarak belirlenir.

\subsection{PROMETHEE Algoritması}

Roy ve arkadaşları [41] tarafindan PROMETHEE (Preference Ranking Organization Method For Enrichment Evaluations), ÇÖKV yöntem olarak öne çıkmıştır. PROMETHEE için algoritma adımları aşağıdaki gibidir $[41,42]$.

Adım 1: Alternatifler, kriterler ve kriterlerin önem dereceleri belirlenip sayısal olarak değer atamaları yapılır ve veri matrisi oluşturulur.

Adım 2: Her bir kriterler için veri tipine göre tercih fonksiyonları tanımlanır. Olağan, U-tipi, V-tipi, seviyeli, doğrusal ve Gaussian olmak üzere altı tip tercih fonksiyonu vardır [43-44].

Adım 3: Alternatif çiftleri için ortak tercih fonksiyonu atanır.

Adım 4: Ortak tercih fonksiyonuna göre her alternatif çifti için tercih değerleri belirlenir. Wi vektörü ağırlıklarına sahip $\mathrm{k}$ kriter için tercih indeksleri hesaplanır [41].

Adım 5: Alternatifler için Eşitlik 11 ve Eşitlik 12 yardımıyla pozitif $(\Phi+)$ ve negatif $(\Phi-)$ üstünlükler hesaplanır [41-42].

$\Phi+(\mathrm{a})=\sum \pi(\mathrm{a}, \mathrm{x}) \mathrm{x}=(\mathrm{b}, \mathrm{c}, \mathrm{d}, \ldots)$ 


$$
\Phi-(a)=\sum \pi(x, a) x=(b, c, d, \ldots z)
$$

Adım 6: Son adımda ise alternatifler için nihai öncelikler hesaplanır ve karar siralaması bulunur.

\section{UYGULAMA}

Kuruluş yeri seçimi uygulaması Şekil 1'de görüldüğü üzere dört aşamadan oluşmaktadır. İlk aşamada kağıt endüstrisi kuruluş yeri için önemli olan kriterlerin belirlenmesi literatür taraması ve uzman görüşlerinin alınması yapılmıştır. İkinci aşamada ise belirlenen kriterlerin ağırlıkları kağıt endüstrisinde faaliyet gösteren üç fabrika yönetici ve sektörde uluslararası çalışmalar yapan yedi öğretim üyesinden elde edilen uzman görüş formları sonuçlarının geometrik ortalaması alınarak kriterlerin ağırlıkları belirlenmiştir.

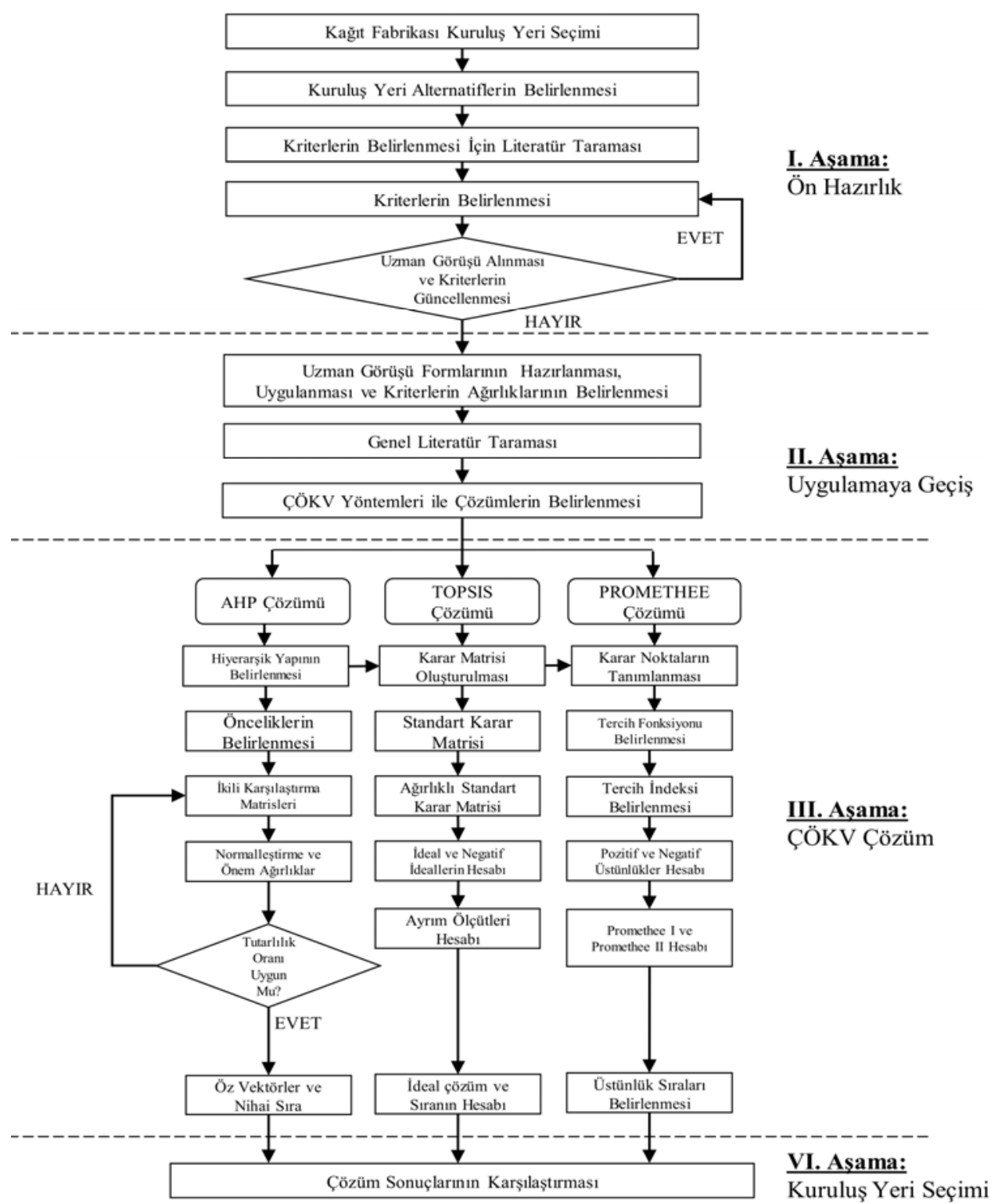

Şekil 1. Kuruluş yeri seçim modeli uygulama aşamaları 
Birden fazla uzman görüș sonuçlarının ortak bir yapıda kabul edilebilir veri oluşturulması gerekmektedir. Saaty [45]'e göre yargıların kendi aralarında farklı önem dereceleri varsa yargıların birleştirilmesi için geometrik ortalamanın kullanılması ile matrislerin oluşturulması uygun olacaktır. Üçüncü aşamada ise AHP, TOPSIS ve PROMETHEE yöntemleri ile alternatifler arasından en uygun kuruluş yeri seçimi için çözümler yapılmıştır. Son aşamada ise, elde edilen sonuçlar karşılaştırılarak en uygun kuruluş yeri belirlenmiştir.

\subsection{Kuruluş Yeri Alternatiflerinin Belirlenmesi}

Çalışmada kuruluş yeri tespit edilirken ilk olarak Akdeniz Bölgesi belirlenmiş daha sonra sektör ve bölge araştırması yapılarak Doğu Akdeniz Bölgesinde karar kılınmıştır. Doğu Akdeniz Bölgesinde Adana, Mersin, Kahramanmaraş, Osmaniye ve Hatay bulunmaktadır. Hatay dışında diğer 4 il merkezleri belirlenmiş Hatay'da ise daha sanayileşmiş ve fabrika kurulumu için uygun olduğu düşünülen İskenderun ilçe merkezi belirlenip alternatifler oluşturulmuştur. Ayrıca nüfus, endüstriyelleşme ve organize sanayi varlığı, atık kağıt tesislerinin bulunması, atık kağıt sağlayan diğer sanayi dalların (ambalaj ve gıda ișleme tesisleri vb.) bölgede yoğun olarak faaliyet göstermesi gibi faktörler bölgesinin seçilmesinde göz önüne alınmıştır. Bölgede büyük çaplı kağıt fabrikaları ve tersine lojistik potansiyelinin bulunması da kuruluş yeri seçiminde önem arz etmektedir. Kuruluş yeri alternatifleri için kriter ağırlıkların belirlenmesinde kullanılan veriler, çeşitli bölgesel araştırma raporları, kalkınma planları, Doğu Akdeniz Kalkınma Ajansı araştırmaları ve istatiksel (TÜİK) bilgiler elde edilmiştir. Ayrıca her kuruluş yeri için yerel çapta belediyeler, kurum ve kuruluşlardan veriler elde edilmiş alternatiflerin ağırlıkları ikili karşılaştırma matrisleri ile belirlenmiştir. Kriter bir kısmı nitel bir kısmı ise nicel verilerden oluşmaktadır. Nitel verilerinde ağırlık verilerek nicel verilere dönüştürülmüştür.

\subsection{Kriterlerin Belirlenmesi}

Kriterlerin belirlenmesi literatür taraması ve kağıt endüstrisinde faaliyet gösteren işletme yöneticiler ve sektörde akademik çalışmalar yürüten akademisyenlerle görüșülüp kriterler belirlenmiștir. Ana kriterler pazar, işgücü, hammadde, ulaşım, teşvikler, atıklar ve su kaynağı, enerji ve arazi olmak sekiz başlıkta oluşturulmuştur. Ayrica her ana kriter alt kriterlere ayrılmış olup açıklamalarıyla birlikte Çizelge 4'de bir bütün halde düzenlenmiştir. Kriterler ve alternatiflerden oluşturulan hiyerarşik yapı Şekil 2'de verilmiştir. Birden çok karar verici tarafindan yapılan değerlendirmelerde ikili karşılaştırma matrisleri ÇÖKV yöntemlerinde kullanılmaktadır. $\mathrm{Bu}$ sonuçların bir uzlaşma sağlayacak şekilde bir araya getirilmesi gerekmektedir. $\mathrm{Bu}$ durumda literatürde en çok kullanılan yöntem her bir karar verici tarafindan oluşturulmuş karşılaştırma matris sonuçlarının geometrik ortalaması alınması yoluyla uzlaşma sağlamaktır [46,47]. Bu çalışmada da her bir kriterin ağırlıklarını belirlemek amacıyla her bir karar verici için uzman görüş formları hazırlanmıştır. Birbirinden bağımsız olarak cevaplanan uzman görüş formlarındaki karşılaştırma matrislerin geometrik ortalaması alınarak nihai kriterlerin ağırlıkları belirlenmiştir.

\subsection{Problemin Çözümü}

\subsubsection{AHP Yöntemiyle Çözüm}

Probleme ilişkin oluşturulan Şekil 2'deki hiyerarşi baz alınarak AHP yöntemiyle çözüm yapılmıştır. Çözümden elde edilen matrisler işlem sırasına göre hazırlanmıştır. Çizelge 3'de kriterlerin ikili karşılaştırma matrisleri verilmiştir. Ayrıca, her bir kriter için alternatiflerin ikili karşılaştırma matrisleri hesaplanmıştır.

Çizelge 3. Kriterlerin ikili karşılaştırma matrisi

\begin{tabular}{|l|c|c|c|c|c|c|c|c|}
\hline & K1 & K2 & K3 & K4 & K5 & K6 & K7 & K8 \\
\hline K1 & 1,000 & 2,137 & 2,433 & 0,863 & 3,252 & 4,373 & 6,714 & 7,203 \\
\hline K2 & 0,468 & 1,000 & 0,504 & 0,672 & 1,280 & 4,767 & 6,901 & 6,137 \\
\hline K3 & 0,411 & 1,984 & 1,000 & 0,313 & 2,324 & 4,373 & 7,942 & 6,637 \\
\hline K4 & 1,158 & 1,487 & 3,194 & 1,000 & 2,067 & 5,073 & 5,593 & 5,820 \\
\hline K5 & 0,308 & 0,781 & 0,430 & 0,484 & 1,000 & 4,593 & 6,593 & 7,949 \\
\hline K6 & 0,229 & 0,210 & 0,229 & 0,197 & 0,218 & 1,000 & 2,449 & 3,091 \\
\hline K7 & 0,149 & 0,145 & 0,126 & 0,179 & 0,152 & 0,408 & 1,000 & 1,620 \\
\hline K8 & 0,139 & 0,163 & 0,151 & 0,172 & 0,126 & 0,323 & 0,617 & 1,000 \\
\hline
\end{tabular}

Kriterler için normalleştirme ve göreli önem ağırlıkları Çizelge 5'de kriterler için normalize matrisleri oluşturulmuştur. Alternatifler içinde normalizasyon matrisleri hesaplanmıştır. 
Çizelge 4. Karar kriterleri ve açıklamaları

\begin{tabular}{|c|c|c|c|c|}
\hline Ana Kriter & Alt Kriter & Tanımlama & Amaç & Kisaltma \\
\hline $\begin{array}{c}\text { Pazar } \\
{[24-25-26-27]}\end{array}$ & $\begin{array}{l}\text { Talep } \\
\text { Pazarların yakınlığ } \\
\text { Satış fiyatlar }\end{array}$ & $\begin{array}{l}\text { Kuruluş yerindeki nüfus ve sektöre talep oluşturacak } \\
\text { endüstri kolların bulunurluğu, OSB varlığı ve büyüklüğü } \\
\text { Şehirleşme ve sanayileşmenin fazla olduğu il ve bölgelere } \\
\text { yakınlık } \\
\text { Bölgede ki diğer kağıt fabrikalarının varlığı ve rekabet } \\
\text { durumu }\end{array}$ & $\begin{array}{l}\text { En çok } \\
\text { En az } \\
\text { En çok }\end{array}$ & K1 \\
\hline $\begin{array}{c}\text { İşgücü } \\
\text { [22-25-26-27] }\end{array}$ & $\begin{array}{l}\text { Fabrika kurulumu } \\
\text { İşgücü düzeyi } \\
\text { İşgücü ücretleri }\end{array}$ & $\begin{array}{l}\text { Kuruluş sırasındaki teknik işgücü kaynaklarının } \\
\text { bulunabilirliği } \\
\text { Fabrikada işleyişi için teknik, idari ve alt kademelerde } \\
\text { gerekli olan İşuücünün potansiyeli ve işgücü sağlayan eğitim } \\
\text { ve meslek kuruluşlarının varlığı } \\
\text { Alt ve üst düzey çalışan işgücü maliyetleri }\end{array}$ & $\begin{array}{l}\text { En çok } \\
\text { En çok } \\
\text { En az }\end{array}$ & $\mathrm{K} 2$ \\
\hline $\begin{array}{l}\text { Hammadde } \\
{[25-26-27]}\end{array}$ & $\begin{array}{l}\text { Tersine lojistik } \\
\text { Yan sanayi } \\
\text { Maliyet }\end{array}$ & $\begin{array}{l}\text { Bölgede kağıt toplama ve geri dönüşüm tesisleri varlığı, } \\
\text { tersine lojistik potansiyeli ve yerel kuruluşların bilinci } \\
\text { Atık kağıt sağlayan sanayi kollarının yoğunluğu (ambalaj, } \\
\text { gıda işleme endüstrisi vb.) } \\
\text { Atık kağıt ve diğer kimyasal hammadde veya yarı mamul } \\
\text { maliyetleri }\end{array}$ & $\begin{array}{l}\text { En çok } \\
\text { En çok } \\
\text { En az }\end{array}$ & K3 \\
\hline Ulaşım [26-27] & $\begin{array}{l}\text { Ulaşım hizmetleri } \\
\text { Geçiş yoğunluğu }\end{array}$ & $\begin{array}{l}\text { Değişik hızlarda çeşitli taşıma (hava, deniz, kara, tren } \\
\text { ulaşımı) ve ulaşım hizmetlerinin varlığı } \\
\text { Yoğun geçiş yol ve limanların bulunma durumu ve } \\
\text { kullanılabilirliği }\end{array}$ & $\begin{array}{l}\text { En çok } \\
\text { En çok }\end{array}$ & K4 \\
\hline $\begin{array}{l}\text { Teşvikler } \\
\text { [26-27] }\end{array}$ & $\begin{array}{l}\text { Teşvikler } \\
\text { Yasal düzenlemeler }\end{array}$ & $\begin{array}{l}\text { Yerel veya merkezi kurum ve kuruluşların ucuz arsa, enerji } \\
\text { ve işçi sigorta vb. özendirme potansiyeli } \\
\text { Kuruluş sırasındaki ruhsat ve izinler vb. hizmetler gereği }\end{array}$ & $\begin{array}{l}\text { En çok } \\
\text { En az }\end{array}$ & $\mathrm{K} 5$ \\
\hline $\begin{array}{c}\text { Atıklar ve } \mathrm{Su} \\
\text { kaynağ } 1[20-23]\end{array}$ & $\begin{array}{l}\text { Kimyasal atıklar } \\
\text { Su kaynakları }\end{array}$ & $\begin{array}{l}\text { Kağıt fabrikası üretim sırasındaki kimyasal atıkların ve } \\
\text { çevreye zarar verebilecek atıkların atılabilme olanakları } \\
\text { Üretimde kullanılacak su kaynaklarının varlığı ve yakınlığı }\end{array}$ & $\begin{array}{l}\text { En çok } \\
\text { En çok }\end{array}$ & K6 \\
\hline Enerji [26] & $\begin{array}{l}\text { Kaynaklar } \\
\text { Maliyet }\end{array}$ & $\begin{array}{l}\text { Kullanılabilir enerji ve yakıt kaynaklarının çeşitliliği ve } \\
\text { potansiyeli } \\
\text { Enerji ve yakıt maliyetleri }\end{array}$ & \begin{tabular}{|l|} 
En çok \\
En az
\end{tabular} & K7 \\
\hline Arazi [23] & $\begin{array}{l}\text { İklim } \\
\text { Jeolojik durum } \\
\text { Maliyet }\end{array}$ & $\begin{array}{l}\text { Bölgenin üretime etki yapacak mevsimsel durumu ve } \\
\text { değişimi } \\
\text { Bölgenin mevcut yer arazi özellikleri } \\
\text { Arazi maliyetleri ve arazi fabrika kuruluş için gerekli } \\
\text { düzenleme maliyetleri }\end{array}$ & $\begin{array}{l}\text { En az } \\
\text { En çok } \\
\text { En az }\end{array}$ & K8 \\
\hline
\end{tabular}

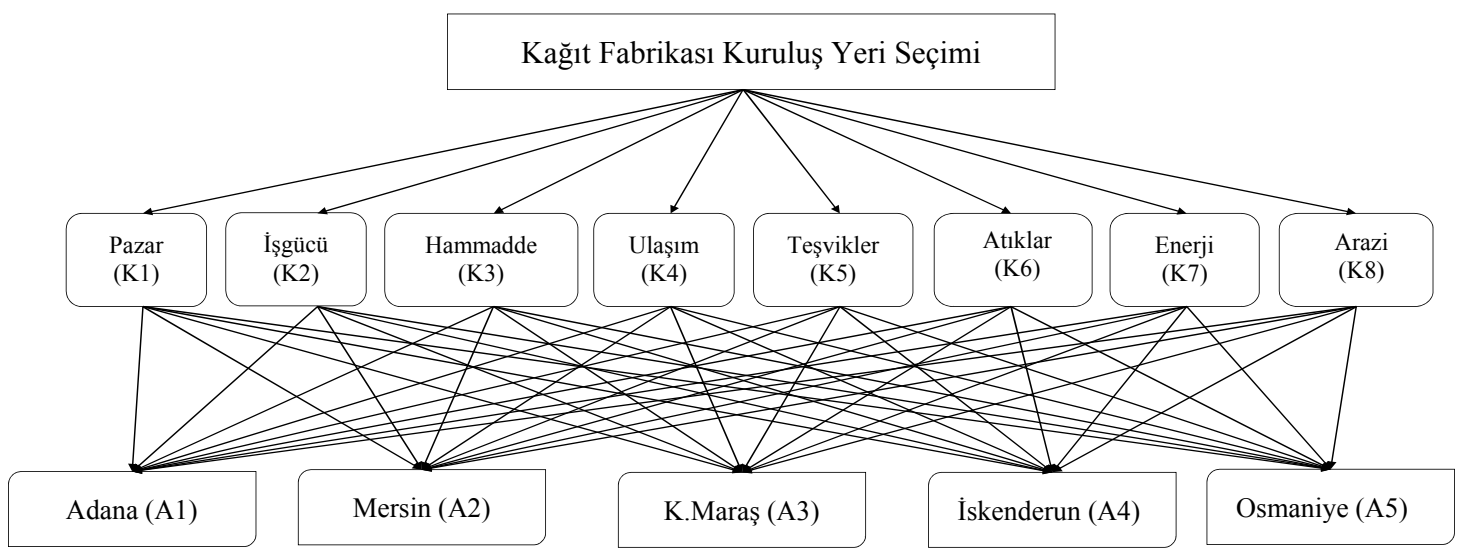

Şekil 2. Uygulamanın hiyerarşik yapısı 
Cizelge 5. Kriterlerin normalizasyon matrisi

\begin{tabular}{|l|c|c|c|c|c|c|c|c|}
\hline & K1 & K2 & K3 & K4 & K5 & K6 & K7 & K8 \\
\hline K1 & 0,259 & 0,270 & 0,302 & 0,222 & 0,312 & 0,176 & 0,178 & 0,183 \\
\hline K2 & 0,121 & 0,126 & 0,062 & 0,173 & 0,123 & 0,191 & 0,183 & 0,156 \\
\hline K3 & 0,106 & 0,251 & 0,124 & 0,081 & 0,223 & 0,176 & 0,210 & 0,168 \\
\hline K4 & 0,300 & 0,188 & 0,396 & 0,258 & 0,198 & 0,204 & 0,148 & 0,147 \\
\hline K5 & 0,080 & 0,099 & 0,053 & 0,125 & 0,096 & 0,184 & 0,174 & 0,201 \\
\hline K6 & 0,059 & 0,027 & 0,028 & 0,051 & 0,021 & 0,040 & 0,065 & 0,078 \\
\hline K7 & 0,039 & 0,018 & 0,016 & 0,046 & 0,015 & 0,016 & 0,026 & 0,041 \\
\hline K8 & 0,036 & 0,021 & 0,019 & 0,044 & 0,012 & 0,013 & 0,016 & 0,025 \\
\hline
\end{tabular}

İkili karşılaştırma matrislerin kabul edilebilir olması için tutarlılık oranları Çizelge 6'da hesaplanmıştır. Bütün matrislerin tutarlılık oranı 0,10'dan küçük olduğu için karar vericilerin kabul edilebilir olduğu söylenebilir. Alternatifler için hesaplanan öz vektörler matrisi Çizelge 7'de verilmiştir.

Çizelge 6. Matrislerin tutarlılık oranları

\begin{tabular}{|l|c|}
\hline Matrisi & Tutarlılık oranı \\
\hline Kriterler & 0,052 \\
\hline Pazar & 0,059 \\
\hline İşgücü & 0,030 \\
\hline Hammadde & 0,019 \\
\hline Ulaşım & 0,030 \\
\hline Teşvikler & 0,020 \\
\hline Atıklar & 0,032 \\
\hline Enerji & 0,032 \\
\hline Arazi & 0,031 \\
\hline
\end{tabular}

Çizelge 7. Alternatiflerin öz vektörleri

\begin{tabular}{|c|l|c|c|c|c|c|}
\hline & & $\mathbf{A 1}$ & $\mathbf{A 2}$ & $\mathbf{A 3}$ & $\mathbf{A 4}$ & $\mathbf{A 5}$ \\
\hline \multirow{7}{*}{$\mathbf{A}=$} & K1 & 0,504 & 0,252 & 0,116 & 0,082 & 0,047 \\
\cline { 2 - 7 } & K2 & 0,462 & 0,303 & 0,113 & 0,073 & 0,049 \\
\cline { 2 - 7 } & K3 & 0,370 & 0,281 & 0,188 & 0,105 & 0,057 \\
\cline { 2 - 7 } & K4 & 0,152 & 0,474 & 0,048 & 0,255 & 0,072 \\
\cline { 2 - 7 } & K5 & 0,060 & 0,075 & 0,140 & 0,234 & 0,491 \\
\cline { 2 - 7 } & K6 & 0,188 & 0,373 & 0,114 & 0,246 & 0,080 \\
\cline { 2 - 7 } & K7 & 0,261 & 0,415 & 0,071 & 0,161 & 0,091 \\
\cline { 2 - 7 } & K8 & 0,084 & 0,066 & 0,263 & 0,189 & 0,397 \\
\hline
\end{tabular}

Hesaplanan kriterlerin öz vektörleri Çizelge 8'de verilmiştir. $\mathrm{Bu}$ öz vektörler her bir kriterin önem ağırlığı olarak kullanılmıştır.

Çizelge 8. Kriterlerin öz vektörleri

\begin{tabular}{|c|l|l|}
\hline \multirow{5}{*}{} & W1 & 0,238 \\
\cline { 2 - 3 } & W2 & 0,142 \\
\cline { 2 - 3 } & W3 & 0,167 \\
\cline { 2 - 3 } & W4 & 0,230 \\
\cline { 2 - 3 } & W5 & 0,127 \\
\cline { 2 - 3 } & W6 & 0,046 \\
\cline { 2 - 3 } & W7 & 0,027 \\
\cline { 2 - 3 } & W8 & 0,023 \\
\hline
\end{tabular}

AHP yönteminin son aşamasında ise kriterlerin öncelikleri ile kriter temelinde bulunan alternatif öncelikleri karşılıklı çarpılarak her bir kuruluş yerinin sahip olduğu öncelik ağırlıkları Çizelge 9'da verilmiştir. AHP yönteminde öncelik ağırlıkları 0 ile 1 aralığında değer almaktadır. Bu değerler içinde 1 'e en yakın alternatif uygun çözüm olarak belirlenir. Bu uygulamada Adana İli'nin en uygun kuruluş yeri olduğu belirlenmiştir. Ayrıca Mersin İli'nin de uygun çözüme çok yakın değer verdiği dikkat çekicidir.

Çizelge 9. AHP yöntemi öncelik Surası

\begin{tabular}{|c|c|c|}
\hline Alternatifler & AHP Sonuç & Seçim Sırası \\
\hline A1 & 0,307 & $\mathbf{1}$ \\
\hline A2 & 0,298 & 2 \\
\hline A3 & 0,117 & 5 \\
\hline A4 & 0,156 & 3 \\
\hline A5 & 0,122 & 4 \\
\hline
\end{tabular}

\subsubsection{TOPSIS Yöntemiyle Çözüm}

AHP yönteminden elde edilen öz vektör ağırlıklarındaki karar matrisleri (A matrisi) 100 ile çarpılarak gibi TOPSIS yönteminde kullanılmıştır. Karar matrisindeki ölçütlere ait puan veya özelliklerin kareleri toplamının karekökü alınarak TOPSIS yönteminde verilen formüle göre Çizelge 10'da görülen standart karar matrisi oluşturulmuştur.

Çizelge 10. Standart karar matrisi

\begin{tabular}{|c|l|c|c|c|c|c|}
\hline & & A1 & A2 & A3 & A4 & A5 \\
\hline \multirow{5}{*}{$\mathbf{F}=$} & K1 & 0,865 & 0,432 & 0,199 & 0,140 & 0,081 \\
\cline { 2 - 7 } & K2 & 0,809 & 0,531 & 0,198 & 0,128 & 0,086 \\
\cline { 2 - 7 } & K3 & 0,718 & 0,545 & 0,366 & 0,204 & 0,110 \\
\cline { 2 - 7 } & K4 & 0,269 & 0,838 & 0,084 & 0,451 & 0,127 \\
\cline { 2 - 7 } & K5 & 0,105 & 0,132 & 0,246 & 0,411 & 0,862 \\
\cline { 2 - 7 } & K6 & 0,374 & 0,739 & 0,226 & 0,487 & 0,158 \\
\cline { 2 - 7 } & K7 & 0,494 & 0,784 & 0,135 & 0,305 & 0,172 \\
\cline { 2 - 7 } & K8 & 0,160 & 0,127 & 0,503 & 0,360 & 0,759 \\
\hline
\end{tabular}

Ağırlıklı standart karar matrisini oluşturmak için öncelikli değerlendirme faktörlerinin ağırlıkları AHP yönteminde bulunan krtiter ağırlıklar (W matrsisi) kullanılmıştır (Çizelge 11). Yöntemde anlatılan formüller kullanılarak hesaplanmıştır. 
Çizelge 11. Ağırlıklı standart karar matrisi

\begin{tabular}{|c|l|c|c|c|c|c|}
\hline & & $\mathbf{A 1}$ & $\mathbf{A 2}$ & $\mathbf{A 3}$ & $\mathbf{A 4}$ & $\mathbf{A 5}$ \\
\hline \multirow{5}{*}{$\mathbf{V}=$} & K1 & 20,544 & 10,274 & 4,725 & 3,328 & 1,922 \\
\cline { 2 - 7 } & K2 & 11,492 & 7,536 & 2,811 & 1,811 & 1,227 \\
\cline { 2 - 7 } & K3 & 12,018 & 9,123 & 6,119 & 3,408 & 1,843 \\
\cline { 2 - 7 } & K4 & 6,179 & 19,257 & 1,935 & 10,357 & 2,921 \\
\cline { 2 - 7 } & K5 & 1,327 & 1,671 & 3,110 & 5,204 & 10,906 \\
\cline { 2 - 7 } & K6 & 1,723 & 3,411 & 1,044 & 2,248 & 0,731 \\
\cline { 2 - 7 } & K7 & 1,341 & 2,128 & 0,366 & 0,826 & 0,468 \\
\cline { 2 - 7 } & K8 & 0,374 & 0,295 & 1,170 & 0,839 & 1,766 \\
\hline
\end{tabular}

TOPSIS yönteminin bir sonraki adımında İdeal (A*) ve negatif ideal (A-) çözüm setleri oluşturulmuştur. Çizelge 12'de her bir kriter için değerler verilmiştir. Sapma değerlerini bulabilmek için hesaplanmış ideal ve negatif ideal ayrım değerleri her bir alternatif için hesaplanmış ve Çizelge 13'de verilmiştir.

Çizelge 12. İdeal ve negatif ideal değerleri

\begin{tabular}{|l|c|c|}
\hline Kriterler & $\mathbf{A}^{*}$ maks & $\mathbf{A}^{-}$min \\
\hline Pazar & 20,544 & 1,922 \\
\hline İşücü & 11,492 & 1,227 \\
\hline Hammadde & 12,018 & 1,843 \\
\hline Ulaşım & 19,257 & 1,935 \\
\hline Teşvikler & 10,906 & 1,327 \\
\hline Atıklar & 3,411 & 0,731 \\
\hline Enerji & 2,128 & 0,366 \\
\hline Arazi & 1,766 & 0,295 \\
\hline
\end{tabular}

Çizelge 13. İdeal ve negatif ideal ayrım değerleri

\begin{tabular}{|l|l|l|l|}
\hline \multicolumn{2}{|c|}{ İdeal } & \multicolumn{2}{c|}{ Negatif İdeal } \\
\hline $\mathrm{S}^{*}{ }_{1}$ & 16,377 & $\mathrm{~S}^{-}$ & 23,993 \\
\hline $\mathrm{S}^{*}{ }_{2}$ & 14,730 & $\mathrm{~S}_{2}$ & 21,749 \\
\hline $\mathrm{S}^{*}{ }_{3}$ & 27,024 & $\mathrm{~S}^{-}$ & 5,718 \\
\hline $\mathrm{S}^{*}{ }_{4}$ & 24,081 & $\mathrm{~S}_{4}$ & 9,672 \\
\hline $\mathrm{S}^{*}{ }_{5}$ & 28,853 & $\mathrm{~S}^{-}$ & 9,742 \\
\hline
\end{tabular}

Her bir karar alternatifin ideal çözüme göreli yakınlık değeri $(\mathrm{Ci} *)$ Çizelge 14 'da verilmiştir. İdeal çözüm değerleri içinde 1' en yakın değere sahip Mersin İli'nin en uygun kuruluş yeri olduğu tespit edilmiştir. Ayrıca, Adana İli'nin de uygun çözüme çok yakın bir sonuç gösterdiği görülmektedir.

Çizelge 14. İdeal çözüme göreli yakınlık

\begin{tabular}{|c|c|c|}
\hline Alternatifler & TOPSIS Sonuç & Seçim SIrası \\
\hline $\mathrm{C}^{*}{ }_{1}$ & 0,594 & 2 \\
\hline $\mathrm{C}^{*}{ }_{2}$ & 0,596 & $\mathbf{1}$ \\
\hline $\mathrm{C}^{*}{ }_{3}$ & 0,175 & 5 \\
\hline $\mathrm{C}^{*}{ }_{4}$ & 0,287 & 3 \\
\hline $\mathrm{C}^{*}{ }_{5}$ & 0,252 & 4 \\
\hline
\end{tabular}

\subsubsection{PROMETHEE Yöntemiyle Çözüm}

PROMETHEE yöntemi çözümünün karışık matematiksel işlemler yapılması gerekmektedir. $\mathrm{Bu}$ maksatla çözüm için hazırlanmış Visual Promethee (Academic Edition 2017) programı uygulama çözümünde kullanılmış ve çözüm adımları ve sonuç ekranları verilmiştir. AHP yönteminden elde edilen kriter ağırlıkları kullanılarak PROMETHEE I ve II'ye göre değerlendirilmiş ve sonuçlar alınmıştır. Yöntemde anlatılan şekilde her bir kriter için uygun tercih fonksiyonunun belirlenmesi gerekmektedir. $\mathrm{Bu}$ maksatla kriter verileri değerlendirilmiş en uygun tercih fonksiyonları belirlenmiştir.

Karar verici tercihini, değerlendirmede ortalamanın üstünde değere sahip karar noktalarından yana kullanmak istiyorsa ve bu değerin altındaki değerleri de ihmal etmek istemiyorsa, Üçüncü Tip (V -shape) tercih fonksiyonu olmalıdır [48]. Kuruluş yeri seçiminde pazar, işgücü, hammadde ve ulaşım kriterleri $\mathrm{V}$ tip tercih fonksiyonunda anlatıldığı gibi verilerden oluşmakta olup uygulamada $\mathrm{V}$ tip kullanılmıştır. Karar verici tercihini değerlendirmelerin ortalamasının üstünde değere sahip karardan yana kullanmak istiyorsa, Beşinci Tip (Linear) tercih fonksiyonu olmalıdır. $\mathrm{Bu}$ uygulamada teşvikte kriteri için Beşinci Tip tercih fonksiyonu kullanılmıştır. Karar vericinin değerlendirmesinde herhangi bir tercih değişimi söz konusu değilse Birinci Tip (Usual) tercih fonksiyonu kullanılmalıdır. Bu uygulamada atıklar, enerji ve arazi kriterlerinin Birinci Tip tercih fonksiyonuna uyduğu belirlenmiştir.

Visual Promethee programı çalıştırılıp çözüm elde edildiğinde her bir kuruluş yeri için +1 ile -1 arasında, pozitif ve negatif değer sonuçları oluşmaktadır. Pozitif değer, ilgili alternatifin diğer alternatiflere göre daha yüksek üstünlügünü, negatif değer ise ilgili alternatifin diğer alternatiflere göre zayıf olduğunu göstermektedir. Şekil 3'de verilen PROMETHEE I'e göre Mersin İli'nin diğer kuruluş yeri alternatiflerine daha baskın olduğu görülmektedir. PROMETHEE II sonuçları Şekil 4'de gösterilmiştir. Değerler incelendiğinde yine Mersin İli'nin ilk sirada tercih edilmesi gerekmektedir. 


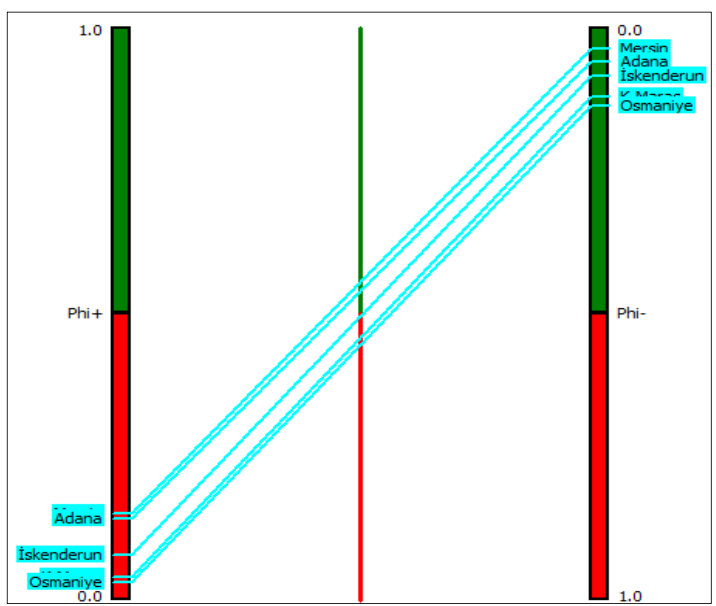

Şekil 3. PROMETHEE I sonuçları

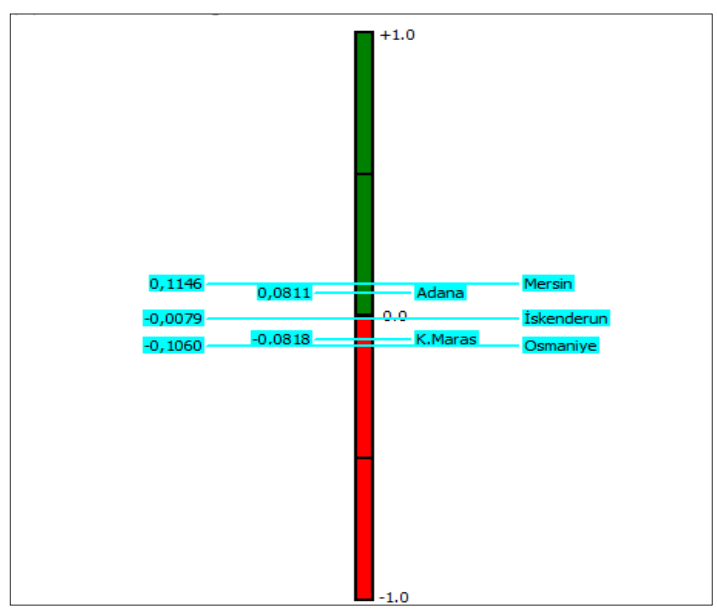

Şekil 4. PROMETHEE II sonuçları

GAIA düzlemi, PROMETHEE yöntemi ile problemlerin çözümünü iki-boyutlu olarak ifade eden en iyi gösterim Şekil 5'de verilmiștir. Yatay eksene yakın olan diğerlerine göre daha kalın doğru, en uygun sonucu göstermektedir. Bu en uygun doğruya yakın olan değerler, incelenen kriterler çerçevesinde seçilmesi gereken alternatifleri göstermektedir. İnce çizgilerle gösterilen kriterlere yakın olan kuruluş yeri incelenen kriter için öncelikli olarak seçilmesi gereken alternatiftir. Sonuçlar değerlendirildiğinde yöntemde en uygun kuruluş yerinin Mersin ili olduğu söylenebilir. Şekil 6'da PROMETHEE ağ yapısı negatif üstünlüklerin ve pozitif üstünlüklerini göstermektedir.

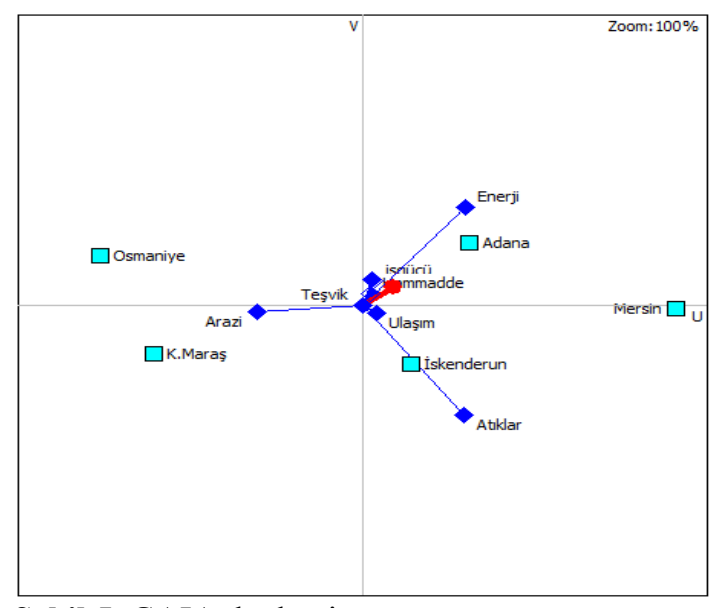

Şekil 5. GAIA düzlemi

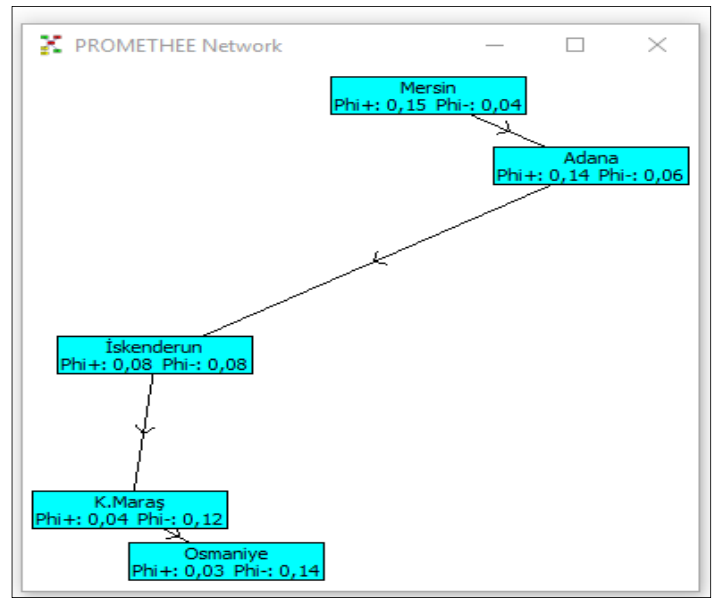

Şekil 6. Ağ yapısı (Network)

\subsection{Sonuçların Karşılaştırması}

Yapılan analizler sonunda yöntemden elde edilen sonuçlar Çizelge 15 'de bir bütün olarak hazırlanmıştır. Sonuçlar karşılaştırıldığında TOPSIS ve PROMETHEE yöntemlerinde en uygun kuruluş yerinin ikinci sıradaki alternatif olan Mersin İli olduğu görülmektedir. Ayrıca AHP yönteminde ilk sirada Adana alternatifi olup Mersin alternatifi ile çok yakın bir değer almıştır. Sonuçlar bir bütünlük halinde değerlendirildiğinde kağıt fabrikası için alternatifler arasından en uygun kuruluş yerinin Mersin ili olduğu söylenebilir. Diğer alternatiflerin öncelik sirası ise Adana, 
İskenderun, Kahramanmaraş ve son sırada Osmaniye yer almıştır.

Çizelge 15. Sonuçların karşılaştırması

\begin{tabular}{|l|c|c|c|}
\hline \multicolumn{1}{|c|}{ Alternatif } & AHP & TOPSIS & PROMETHEE \\
\hline Adana & 1 & 2 & 2 \\
\hline Mersin & 2 & $\mathbf{1}$ & $\mathbf{1}$ \\
\hline K.Maraş & 5 & 5 & 4 \\
\hline İskenderun & 3 & 3 & 3 \\
\hline Osmaniye & 4 & 4 & 5 \\
\hline
\end{tabular}

\section{SONUÇ VE ÖNERILER}

İşletme maliyetleri en aza indirmek ve kaynak kullanımını en üst düzeye çıkarmak için, tesis yeri seçmek, üretim işletmeleri için uzun vadede etkin olan en önemli konulardan biridir. Bu çalışmada, bir fabrika yeri seçimi problemi için üç farklı ÇÖKV yöntemleri ile karar destek modeli geliştirilmiştir. $\mathrm{Bu}$ amaçla, ön adım olarak literatür taraması ve uzman görüşleri ile etkili kuruluş yeri kriterler belirlenmiş ve önem dereceleri entegre olarak yapılandırılmıştır. Daha sonra belirlenen önem dereceleri AHP, TOPSIS ve PROMETHEE yöntemleri için girdi ağırlıkları olarak kullanılmıştır. Son olarak da, önerilen metodolojinin uygulanabilirliğini ve uygunluğunu göstermek için kuruluş yeri seçimi uygulama örneği sunulmuştur. $\mathrm{Bu}$ uygulamada atık kağıt endüstrisine hitap edecek bir yüksek yatırımlı fabrika yerinin belirlenmesi probleminde ÇÖKV yöntemlerinin kullanılabileceği gösterilmiştir. $\mathrm{Bu}$ maksatla sektörel kısıtlar göz önüne alınarak kağıt endüstrisinde kuruluş yeri seçim problemi için genel ve tamamlayıcı bir öneri uygulaması sunulmuştur.

Çalışmanın uygulamasında, kuruluş yeri üzerine pazar, ulaşım ve hammadde kriterinin yüksek etkiye sahip olduğu görülmüştür. Ayrıca diğer kriterler ise sırayla işgücü, teşvikler, enerji ve arazi özellikleri olarak belirlenmiştir. Kuruluş yeri alternatifleri olarak Adana, Mersin, Kahramanmaraş, İskenderun ve Osmaniye olarak belirlenmiştir. ÇÖKV yöntemleri ile bu kriterler ve alternatifler yöntemlerin algoritmalarında anlatılan adımlar uygulanarak çözümler elde edilmiş ve sonuçlar karşılaştırılmıştır. Sonuçta en uygun kuruluş yerinin Mersin İli olduğu görülmüştür. Ayrıca diğer alternatifler ise sırasıyla Adana, İskenderun, Kahramanmaraş ve Osmaniye olduğu yapılan değerlendirmeler sonucu belirlenmiştir.

Uluslararası çalışmalarda kağıt endüstrisinde kuruluş yeri çalışmalarının çok kısıtlı olması ve Türkiye'de atık kağıttan üretim yatırımı için kuruluş yeri belirlemesi ile ilgili çalışmaların daha önce yapılmamış olmasından dolayı sektörel kuruluş yeri kriterlerinin belirlenmesi ve bir bütün halde uygulanması çalışmaya önem katmıştır. Yapılan bu çalışmanın benzer sektördeki ve bölgedeki yatırımcılara katkı sağlayacağı düşünülmektedir.

Son olarak, bu uygulama çeşitli yönlerden genişletilebilir. Sektöre özgü kısıtlamaların etki ağırlığı artırılarak ve daha geniş kapsamlı yatırım projelerinde çalışmalar yapılabilir. Ayrıca farklı veya benzer sektörlerde yapılacak kuruluş yeri problemlerinde doğrusal programla modellerin ve/veya bulanık mantıkla entegre modellerin geliştirilmesi önerilebilir.

\section{KAYNAKLAR}

1. Akkayan, S.C., 1979. Türkiye'de Kağıt ve Karton Üretiminin Özel Sektör Yönünden İncelenmesi, Journal of the Faculty of Forestry Istanbul University, 183-199.

2. Gürbüz, O. 1995. Türkiye'de Kağıt Sanayii ve Silifke-Taşucu Kağıt Fabrikası. Türk Coğrafya Dergisi, (30), 225-242.

3. Çevik, B., 2016. Kâğıt ve Kâğıt Ürünleri Sektörü, İş Bankası İktisadi Araştırmalar Raporu, https://ekonomi.isbank.com.tr/User Files/pdf/sr20607_kagitsektoru.pdf, May1s, 2016. Erişim Tarihi: Şubat 5, 2018.

4. Yildırım, H., Yavan, Ö., 2012. KİT’lerde Özelleştirme Sonrası Yeniden Yapılanma: Çaycuma SEKA Örnek Uygulaması. Uluslararası Yönetim İktisat ve İşletme Dergisi, 3(5), 117-138.

5. Cakir, H., Yildirim Gonul, B., 2015. Tarihi Yapılarda Mekansal Belleğin Korunması: İzmit SEKA Selüoz ve Kağıt Fabrikasının Dönüşümü, Beykent Üniversitesi Fen ve Mühendislik Bilimleri Dergisi, 8(2), 85-110.

6. Sakarya, S., Canlı, Ş., 2011. Kâğıt Karton Sanayi Sektör Raporu, Orta Anadolu İhracatçı Birlikleri, 
Orta Anadolu Ağaç Mamulleri ve Orman Ürünleri İhracatçıları Birliği, 1-42.

7. Yorulmaz, H., 2014. Doğu Marmara Bölgesi Kâğıt Sanayi Sektör Raporu, Doğu Marmara Bölgesi Kalkınma Ajansı, Bölge Planı Yayını serisi (16), 1-38.

8. Zaimoğlu, S., 2012. Kağıt ve Kağıt Ürünleri Sektör Meclisi Raporu, Türkiye Odalar ve Borsalar Birliği (TOBB) https://www.tobb. org.tr, Ocak, 2012. Erişim Tarihi: Şubat 5, 2018.

9. Kannan, D., Khodaverdi, R., Olfat, L., Jafarian, A., Diabat, A., 2013. Integrated Fuzzy Multi Criteria Decision Making Method and Multiobjective Programming Approach for Supplier Selection and Order Allocation in a Green Supply Chain, Journal of Cleaner Production, 47, 355-367.

10. Macharis, C., Bernardini, A., 2015. Reviewing the use of Multi-Criteria Decision Analysis for the Evaluation of Transport Projects: Time for a Multi-actor Approach, Transport Policy, 37, 177-186.

11. Dağdeviren, M., 2007. Bulanik Analitik Hiyerarşi Prosesi ile Personel Seçimi ve Bir Uygulama, Journal of the Faculty of Engineering and Architecture of Gazi University, 22(4), 791799.

12. Küçükoğlu, İ., Yagmahan, B., Onaylı, A., Çayhan, E.D., Ünal, M., 2017. Application of Goal Programming Integrated Multi-Criteria Decision Making Approaches for the Stock Area Selection Problem of an Automotive Company. International Journal of Supply Chain Management, 6(3), 187-198.

13. Velasquez, M., Hester, P.T., 2013. An Analysis of Multi-criteria Decision Making Methods, International Journal of Operations Research, 10(2), 56-66.

14. Ertuğrul, İ., Karakaşoğlu, N., 2014. Comparison of Fuzzy AHP and Fuzzy TOPSIS Methods for Facility Location Selection, The International Journal of Advanced Manufacturing Technology, 39(7-8), 783-795.

15. Badri, M.A., 1999. Combining the Analytic Hierarchy Process and Goal Programming for Global Facility Location-allocation Problem. International Journal of Production Economics, 62(3), 237-248.
16. Drezner, Z. (Ed.), 1999. Facility Location: a Survey of Applications and Methods. Springer Verlag.

17. Farahani, R.Z., Steadie Seifi, M., Asgari, N., 2010. Multiple Criteria Facility Location Problems: A Survey. Applied Mathematical Modelling, 34(7), 1689-1709.

18. Jamshidi, M., 2009. Median Location Problem, in Facility Location, Facility Location Concepts, Models, Algorithms and Case Studies Farahani, R. Z., (ed.), Springer-Verlag Berlin Heidelberg, 177-191.

19. Kahraman, C., Ruan, D., Doğan, I., 2003. Fuzzy Group Decision-making for Facility Location Selection, Information Sciences, 157, 135-153.

20. Özcan, T., Çelebi, N., Esnaf, Ş., 2011. Comparative Analysis of Multi-criteria Decision Making Methodologies and Implementation of a Warehouse Location Selection Problem, Expert Systems with Applications, 38(8), 9773-9779.

21. Tavakkol1, M.R., Mousavi, S.M., Heydar, M., 2011. An Integrated AHP-VIKOR Methodology for Plant Location Selection, International Journal of Engineering-Transactions B: Applications, 24(2), 127-137.

22. Mousavi, S.M., Tavakkoli-Moghaddam, R., Heydar, M., Ebrahimnejad, S., 2013. Multicriteria Decision Making for Plant Location Selection: an Integrated Delphi-AHPPROMETHEE Methodology. Arabian Journal for Science and Engineering, 38(5), 1255-1268.

23. Choudhary, D., Shankar, R., 2013. An STEEPFuzzy AHP-TOPSIS Framework for Evaluation and Selection of Thermal Power Plant Location: A Case Study from India. Energy, 42(1), 510-521.

24. Lundmark, R., 2011. Choice of Location for Investments in the European Paper Industry: the Impact of Wastepaper. Resources, Conservation and Recycling, 33(3), 167-180.

25. Braglia, M., Gabbrielli, R., 2011. A Decision Support System for Locational Analysis in Paper Industry. International Journal of Logistics Systems and Management, 11(1), 38-55.

26. Vali, M., Rafighi, A., Azizi, M., Mohebbi, N., 2013. Optimal Site Selection for Fluting Paper Mill from Agricultural Wastes in Golestan Province, Iran. International Journal of Sustainable Engineering, 6(1), 23-30. 
27. Barimani, A., Ghasemian, A., Azizi, M. Zabizadeh, S.M., 2014. Optimized Locating of Fluting Paper Plant from Agricultural Residues Using AHP (Based on benefit and cost approach), International Journal of Lignocellulosic Products, 1(2), 104-120.

28. Greco, S., Ehrgott, M., Figueira, J.R. (ed.), 2016. Multiple Criteria Decision Analysis: State of the Art Surveys. Springer.

29. Pohekar, S.D., Ramachandran, M., 2004. Application of Multi-criteria Decision Making to Sustainable Energy Planning-a Review. Renewable and Sustainable Energy Reviews, $8(4), 365-381$.

30. Yoon, K.P., Hwang, C.L., 1995. Multiple Attribute Decision Making: an Introduction (Vol. 104), Sage publications.

31. Myers, J.H., Alpert, M.I., 1968. Determinant Buying Attitudes: Meaning and Measurement. The Journal of Marketing, 32 (4), 13-20.

32. Saaty, T.L., 1977. A Scaling Method for Priorities in Hierarchical Structures. Journal of Mathematical Psychology, 15(3), 234-281.

33. Saaty, T.L., 1990. How to Make a Decision: the Analytic Hierarchy Process, European Journal of Operational Research, 48(1), 9-26.

34. Saaty, T.L., 1994. How to Make a Decision: the Analytic Hierarchy Process. Interfaces, 24(6), 19-43.

35. Saaty, T.L., 2016. The Analytic Hierarchy and Analytic Network Processes for the Measurement of Intangible Criteria and for Decision-making. In Multiple Criteria Decision Analysis. Springer, New York, 363-419.

36. Saaty, T.L., Vargas, L.G., 2001. The Seven Pillars of the Analytic Hierarchy Process. In Models, Methods, Concepts \& Applications of the Analytic Hierarchy Process, Springer US, 27-46.

37. Yoon, K., Hwang, C.L., 1981. TOPSIS (technique for Order Preference by Similarity to Ideal Solution)-a Multiple Attribute Decision Making, w: Multiple Attribute Decision Makingmethods and Applications, a State-of-the-at Survey, Berlin: Springer Verlag, 128-140.

38. Lai, Y.J., Liu, T.Y., Hwang, C.L., 1994. Topsis for MODM. European Journal of Operational Research, 76(3), 486-500.
39. Monjezi, M., Dehghani, H., Singh, T.N., Sayadi, A.R., Gholinejad, A., 2012. Application of TOPSIS Method for Selecting the Most Appropriate Blast Design. Arabian Journal of Geosciences, 5(1), 95-101.

40. Hwang, C.L., Lai, Y.J., Liu, T.Y., 1993. A New Approach for Multiple Objective Decision Making. Computers \& Operations Research, 20(8), 889-899.

41. Roy, B., Vinche, P., Mareschal, B., 1981. How to Select and How to Rank Project: The PROMETHEE Method, European Journal of Operational Research, br, 24, 207-218.

42. Uzun, S., 2015. Gemi İnşa Sürecinde Ana Makine ve Jeneratör Seçimi: Ahp, Topsis ve Promethee Uygulaması, Yüksek Lisans Tezi, Gebze Teknik Üniversitesi, Gebze.

43. Brans, J.P., Vincke, P., 1985. Note-A Preference Ranking Organisation Method: (The PROMETHEE Method for Multiple Criteria Decision-Making), Management science, 31(6), 647-656.

44. Opricović, S., 1998. Multicriteria Optimization of Civil Engineering Systems. University of Belgrade-Faculty of Civil Engineering, Belgrade, 2(1), 5-21.

45. Saaty, T.L., 2008. Relative Measurement and its Generalization in Decision Making Why Pairwise Comparisons are Central in Mathematics for the Measurement of Intangible Factors the Analytic Hierarchy/network Process. RACSAM-Revista de la Real Academia de Ciencias Exactas, Fisicas y Naturales. Serie A. Matematicas, 102(2), 251-318.

46. Saaty, T.L., 1980. The Analytic Hierarchy Process: Planning, Priority Setting, Resources Allocation, New York: McGraw.

47. Rangone, A., 1996. An Analytical Hierarchy Process Framework for Comparing the Overall Performance of Manufacturing Departments. International Journal of Operations \& Production Management, 16(8), 104-119.

48. Dinçer, S.E., Ekin, E., Karakaş, K.S., 2017. Promethee Yöntemiyle Uçak Komponentlerinin Önceliklendirilmesi Problemlerine Çözüm Yaklaşımı, Sosyal Bilimler Araştırma Dergisi, 6(3), 106-125. 